\title{
Old Wine in New Bottles: Drug Repurposing
}

\author{
Shahper N Khan* \\ Interdisciplinary Biotechnology Unit, AMU, India
}

Submission:December 29, 2016; Published: January 30, 2017

*Corresponding author: Shahper N Khan, Interdisciplinary Biotechnology Unit, AMU, Aligarh 202002, India, Email: shahper01@gmail.com

\section{Editorial}

Above $90 \%$ of lead molecules first tested in phase I studies often fails to reach the market. Many thousands of compounds do not even complete clinical trials, which further add to the cost burden to new drug discovery projects. Faced with scientific and economical challenges the possibility of finding new indications of existing drugs is an attractive proposition. Hence, recently the field of drug repurposing or repositioning has fuelled extensive research in academic as well as industrial sector [1-3].

Previously, it was a serendipitous process wherein chance observations suggest new indications for an approved drug or drug candidate. In recent years, molecules rejected in drug company pipelines due to lack of efficacy or unwanted toxicity have received adequate endorsement for repurposing. Such compounds could be exceptional assets as they already have detailed safety and activity profiles. Indeed, repurposed drugs can be approved faster with as little as $\sim 60 \%$ the cost and with three times lower attrition rates than a drug from a traditional drug discovery approaches [4]. Though it can be questioned as not to depict an absolute innovation, like the discovery of some novel molecular target would have represent. Nevertheless, these new indications from available drugs will pace our progress toward achieving the cure for a disease at much faster rate.

However, the low available data on mechanistic action of traditional drug-repositioning methods makes it difficult to reach unmet medical goals by successfully repositioning a huge number of existing drugs. In recent years, the frequency of drugrepositioning methods and its acceptance has dramatically increased. It is essential to better understand these existing methods and prioritize them based on specific studies [5]. Application of an efficient drug-repositioning pipeline to a specific study needs identification of feasible methods based on available information of the drugs or diseases of interest.

Among the various popular approaches evolved computational drug repurposing is far more efficient. These methods focus on various orientations, predicted by available data and reported mechanisms either on drug, disease pathology or treatment outcomes. These in silico drug-repositioning methods enable researchers to examine nearly all drug candidates and test on a relatively large number of diseases within drastically shortened time lines. They can be classified as target-based, knowledge-based, signature-based and network-based and can be chosen as per the need of the study [6]. Whereas most of the abovementioned computational drug repurposing methods rely on different types of structured data sets, Persidis et al. [7] showed the significance of literature mining and its use in extracting applicable data from freely available texts [7]. Such data can subsequently be mined and visualized for identifying novel indications for existing drugs. In a comprehensive review by Hong et al. [8] prospects of drug repositioning employing network pharmacology are well discussed [8]. Wherein they focused on drug off-targets discovery and relationship between drug targets and disease-associated proteins.

Besides implementing the right strategy for successful drug repositioning, it is also very important to know which drug or drug target needs to be focused. With a medicine like aspirin, it is easy to see why we are mostly not interested in researching a new therapeutic property unless it can be used as leverage for the consumers to choose it over the existing brand. And many would reconsider the ethics of doing so, as why to bring an expensive repositioned product, when an affordable option exists.

Future emphasis need to be made that drug repositioning studies have to be solidly grounded on science to get a successful end result. Furthermore, the field needs better development of more in-depth mechanistic approaches that can easily be translated into drug repositioning pipelines that integrate computational and experimental methods seamlessly to ensure high success rates of repositioned drugs.

\section{References}

1. Novac N (2013) Challenges and opportunities of drug repositioning. Trends Pharmacol Sci 34(5): 267-272. 
2. Oprea TI, Bauman JE, Bologa CG, Buranda T, Chigaev A, et al. (2011) Drug repurposing from an academic perspective. Drug Discov Today Therap Strategies 8(3-4): 61-69.

3. Collins FS (2011) Mining for therapeutic gold. Nature Rev Drug Discov $10(6): 397$.

4. Chong CR, Sullivan DJ (2007) New uses for old drugs. Nature 448(7154): 645-646.

5. Jin G, Wong ST (2014) Toward better drug repositioning: prioritizing and integrating existing methods into efficient pipelines. Drug Discov Today 19(5): 637-644.
6. Li J, Zheng S, Chen B, Butte AJ, Swamidass SJ, et al. (2016) A survey of current trends in computational drug repositioning. Brief Bioinform 17(1): 2-12

7. Andronis C, Sharma A, Virvilis V, Deftereos S, Persidis A (2011) Literature mining, ontologies and information visualization for drug repurposing. Brief Bioinform 12(4): 357-368.

8. Ye H, Wei J, Tang K, Feuers R, Hong H (2016) Drug Repositioning Through Network Pharmacology. Curr Top Med Chem 16(30): 36463656

\section{Your next submission with Juniper Publishers} will reach you the below assets

- Quality Editorial service

- Swift Peer Review

- Reprints availability

- E-prints Service

- Manuscript Podcast for convenient understanding

- Global attainment for your research

- Manuscript accessibility in different formats

(Pdf, E-pub, Full Text, Audio)

- Unceasing customer service

Track the below URL for one-step submission https://juniperpublishers.com/online-submission.php 